\title{
Ratio Between Outsourcing Management Efficiency and Financial Results: Case Study in Brazilian Companies
}

\author{
Henrique de Castro Neves ${ }^{1}$, José Carlos de Souza Colares ${ }^{2}$, João Bosco Favero ${ }^{3}$, Bruno Botelho Piana ${ }^{4}$ \& Rosangela \\ Aparecida da Silva ${ }^{5}$ \\ ${ }^{1}$ Business Administration, Universidad Nacional de La Matanza, Buenos Aires, Argentina \\ ${ }^{2}$ Public Finance and State Administration, Universidad Nacional de La Matanza, Buenos Aires, Argentina \\ ${ }^{3}$ Public Administration, Universidad Nacional de La Matanza, Argentina \\ ${ }^{4}$ Public Administration. Universidade Federal de Rondônia, Brazil \\ ${ }^{5}$ Faculdade União das Escolas Superiores de Rondônia, UNIRON, Brazil \\ Correspondence: Henrique de Castro Neves, Postgraduate Program in Economic Sciences, Business Administration, \\ Universidad Nacional de La Matanza, Buenos Aires, Argentina.
}

Received: October 20, 2021

Accepted: November 29, 2021

Online Published: March 6, 2022

doi:10.5430/ijba.v13n2p67

URL: https://doi.org/10.5430/ijba.v13n2p67

\begin{abstract}
The objective of this article was to investigate the impact of the efficiency level in the management of outsourcing on corporate financial results. For this, two companies in the industrial sector that adopted the outsourcing method in their operations were selected, considering the period from 2015 to 2019. The research is a descriptive exploratory case study with a quali-quantitative method. For the data collection, an instrument was used consisting of 8 (eight) management process efficiency indicators (iTEPG), 4 (four) analysis criteria and 5 (five) evaluation standards, intended for the formation of the Efficiency Rate. To define the Efficiency Rate, a mathematical model built from the literature studied was used. In order to reach the research objective, analyses were carried out in the financial and management reports, based on the Business Process Outsourcing (BPO) method. The results showed that the negative impacts on these company's financial results are directly related to the low level of efficiency in the BPO management process, and it can be said with reasonable certainty that poor outsourcing management contributes decisively to negatively impact in the financial results of organizations.
\end{abstract}

Keywords: management process, outsourcing efficiency, profitability

\section{Introduction}

The economic development of an institution must be a permanent objective of business managers, given their responsibility in the universe of the social function of property, whose purpose is to expand the economic concept of the organization to, in addition to profit, produce wealth and goods that meet the needs of society. Therefore, administrators must be committed to building a solid economic development for the institution, supported by efficient procedures capable of producing effective results and generating the necessary effectiveness to combat and mitigate undesirable situations. It should be noted that, for the sake of ownership, no managerial activity is exempt from this assumption, under penalty of compromising the financial results and, wherefore, all the results obtained by the entities over time.

In this sense, science has several administrative support management tools whose purpose is to promote business efficiency. It can even be suggested that these instruments have a single purpose: to maintain the company's sustainable economic growth and to ensure its survival in the market, generating profits for shareholders, employment and income for the population. Accordingly, managers need to adopt measures that minimize negative impacts and maximize results, using the management tools and available resources in the most competent way possible.

For the exercise of this task, business managers have a wide range of procedures that, supported by administrative tools, lend themselves to assisting in the performance of the management of the company. Nonetheless, this range of mechanisms will do nothing if management is not efficient. From this assumption arises the need for administrators 
to be trained to undertake competent governance and to develop skills to manage business activities to the best advantage possible.

Among the many management tools available, the cost management is one of the most used for managing companies, once the issue of expenses is always a demand that requires specific knowledge, in addition to unique skills and attitudes on the part of the manager. Several studies have already shown that, due to poor cost management, a number of companies sank within two years of existence, and some with long years of life. On the other hand, successful companies always have healthy economic management as a backdrop. Another tool that stands out for the administrator's assistance is the process denominated outsourcing. This method has been shown to be a complementary element that boosts favourable financial results, due to the possibility of transferring fixed costs to variable costs, which makes possible to boost operating results and profitability. Acting together, these two tools can provide considerable gains to organizations, which cooperates for a better performance of the company, making everyone: company, owners, investors and employees became benefited.

Then, this research seeks to identify the relationship between management efficiency and financial results, specifically with regard to the outsourcing governance. The results showed that there are substantial differences when the requirements of good management are competently applied and when they are neglected. The losses or gains, over time, have shown that, increasingly, it is necessary for entrepreneurs to invest in the training and professionalization of managers, so that business efficiency is effectively achieved and, with it, the financial results be attractive and sustainable.

\section{Research Problem and Objectives}

This research seeks to identify the effects of governance in outsourcing management on the company's financial results. Thus, the main objective of this study is to verify whether, in the implementation and management of outsourcing, competitive advantages in costs were obtained and what the behaviour of these advantages over time, due to the ability of administrators to undertake efficient management in related processes. As complementary objectives, the following are sought: (i) to identify the financial performance of companies within a period of five years after the outsourcing implementation; (ii) to study the structure of the outsourcing management process; and (iii) to measure the impacts on financial results arising from the degree of efficiency in managing this process.

\section{Theoretical Review}

This item exposes the concepts that comprise this work. There is useful information from renowned authors on the subject, which aim to provide referential support for the research. This part discusses the issue of cost management, cost competitive advantages, the outsourcing process and related management models. The intention is to provide sufficient support to meet the research objectives.

\subsection{Outsourcing}

Rezende (2019) indicates that the outsourcing of services has been heavily influenced by emerging technologies, thus becoming a method of continuous innovation for improving enterprise management and implementing advanced business governance. The author emphasizes that outsourcing is an administrative tool with relevant potential to reduce organizational costs, which allows the reinvestment of part of the amount saved and enables investments that are more focused on the company's main products. In this sense, the author relates outsourcing to competitive advantage as he considers that outsourcing is a process of disruption that allows considerable gains capable of leveraging the advantages obtained in terms of costs in organizations, making the company more agile, efficient and effective.

Uemoto Filho (2019) notes that the expression third party contracting is commonly known as outsourcing and can be understood as a business management model where services related to the most tactical part of the business are transferred and, sometimes, covers the strategic area. By implementing outsourcing services, the company aims to reduce costs and maximize efficiency, in addition to contributing to the streamlining of the work team and increasing the level of team performance and boosting product quality. As a result of the process, employees' efforts are concentrated on specific tasks, generating greater productivity and quality in the product or service. Furthermore, outsourcing provides the identification of better investments and has the potential to improve customer service. Moreover, outsourcing also offers the possibility of improving the user service and implementing new technological solutions, all without the company losing strategic intelligence.

In the list of advantages brought by outsourcing, the following can be highlighted: greater concentration on the strategic vision of the business; cost reduction; process simplification; maximizing production capacity through the use of resources available from third parties; better use of the organization's staff time and effort; availability of a 
specialized supplier for the required activity; and reduction and/or minimization of technical incompetence (VALENÇA \& BARBOSA, 2002; SÁ, BOMTEMPO \& QUENTAL, 1998; FARIA, 2008).

As disadvantages, outsourcing can present: conflicts of interest, in case the outsourced company provides the same service to the contracting party's competitor; low alignment with the company's strategy; and excessive dependence on the outsourced. In addition, there is a risk that outsourcing will not work, which can result in losses, since the eventual return to the in-house production model can be costly. Despite this, the outsourcing process always offers more advantages than disadvantages, it is only necessary that companies take due care in partner selection and in the preparation of contracts in order to avoid subcontracting inexperienced people or those unable to meet the demand, as well as avoid contractual spaces from which opportunistic demands may arise (FREITAS, ALMEIDA \& OLIVEIRA, 2017).

Ellram, Tate and Billington (2008) state that the practice of outsourcing is not exactly new in the business world. For the authors, this debate about the implementation, benefits, advantages and disadvantages of outsourcing activities has existed since the creation of the first business entities. The authors emphasize that outsourcing provides alternatives for cost reduction and allows the organization to keep the focus of activities on the core business, with a strong possibility of being employed even in core activities. The authors also highlight that the outsourcing of non-essential activities opens ways to maximize the profit margin and provides flexibility to the company. Furthermore, the practice gives administrators the possibility of transforming fixed costs into variable costs in order to obtain the benefits of economies of scale. The authors warn, however, that for the implementation of outsourcing to generate favourable results, there must be an efficient model of process management.

\subsection{Outsourcing Management Through BPO}

BOUKADI et al (2019) note that the Business Process Outsourcing (BPO) stands out for its efficient application in the outsourcing process. For the authors, the BPO is relevant for its ability to provide infrastructure of hardware, software, applications, technical support and specialized labour. Moreover, the tool assists in the transition of processes from a contracting entity to a contracted partner whom, in turn, assumes the role of executing the primary tasks and even the main activities of the organization. The objective is to reduce costs and improve the quality of products and services provided. All of this makes the BPO contributes to increasing productivity and, consequently, the positive financial results.

ZAROUR and BENMERZOUG (2019) highlight that the Business Process Outsourcing (BPO) is a business organization and management tool where a company is hired to carry out work for other companies, it is important to understand that the BPO is not a consultancy, providing technical assistance directed at the business part model to solve specific problems. On the contrary, a company that provides services using the BPO methodology assumes a relevant sector or activity of the company in its entirety, whether from the backoffice or front-office. Thus, when opting for the BPO methodology, the company seeks a partner who is fully in charge of a certain task or department, in addition to accrete know-how and bringing differentials such as qualification, technological innovations and process innovation, making room for the company to return its focus on the core business and, as a result, obtain cost savings and a leaner and more focused operation.

According to Maia (2017), for the Business Process Outsourcing to be implemented efficiently and be successful, it is necessary to comply with the fundamental rules that will underpin the process, among which the following stand out: (i) the strategic decision; (ii) the long-term thinking; (iii) the systematic study of the structure; (iv) the efficient identification of costs incurred in the process (v) the effective mapping of internal processes; (vi) prior identification of direct and indirect benefits to be achieved; (vii) an adequate selection of partners; (viii) the delimitation of the service level agreement (SLA) of the selected partner; (ix) the choice of activities subject to outsourcing; ( $x$ ) the analysis of process risks; (xi) an efficient method of monitoring and control; and (xii) the issuance of periodic reports to verify the effectiveness of the process.

By correctly following the model, it is possible to achieve agility in decisions, maximization of profitability, reduction of costs and waste, in addition to increasing quality, becoming an important component for business performance, as prescribed by Eckert, Martins and Gonçalves (2017).

\subsection{Cost Management}

Machado (2018) indicates that strategic cost management is related to the efficient use of financial data for the development and mapping of superior strategies capable of producing sustainable competitive advantage. Thus, cost management, when performed efficiently, generates information able to support decision making. Thus, the method 
is aimed to identifying the chances of cost reduction that can generate advantages over competitors and generate gains in competitiveness.

Martins (2018) teaches that strategic cost management is applied through administrative tools designed to place the company in a prominent position in the market, generating important information that results in a competitive advantage for organizations. Thus, efficient cost management is a technique that encompasses innovative procedures determined to respond to the demands of the environmental characteristics of the highly competitive market, in order to help companies to remain competitive. The author notes that strategic cost management indicators can be separated into at least three directions: firstly, the costs must be market-oriented (external environment); in the background, costs must be oriented towards competitors; and finally, the costs must be considered in the long term.

In sight of this, Souza et al (2017) highlight that five tactics can be applied to achieve cost efficiency, namely: (i) $\mathrm{ABC}$ costing, which measures and manages the costs of resources and allocating them to activities by drivers of resources; (ii) the life cycle cost, which measures the relevant course of purchasing a given good from the analysis of the supply chain; (iii) cost of quality, that analyse the cost-effectiveness of quality management, separating the expenses with quality management and the loss suffered by the non-quality of the product or service; (iv) target costing, whose objective is to reduce costs before production, achieved through the cooperation of many departments, which may even be through partners; and (v) the costing of the value chain, which involves the relationship between the company and its partners, such as suppliers, service providers and even customers.

In this sense, Padoveze (2018) indicates that one of the most efficient strategies is the conversion of fixed costs into variable costs, which can be achieved through outsourcing. However, for this procedure to have the desired effects, it is essential that the process is conducted with the necessary competence and with the due quality. In this way, it is verified that the fixed costs are represented by the expenses of the fixed inputs and the variable costs are the expenses of the variable inputs. Thus, if there is an increase in production and there is no increase in inputs, the cost is fixed, but if it is necessary to increase the costs of fixed inputs in the short term, the input becomes variable and, consequently, its cost too. Thereby, the behaviour of production input costs in relation to short-term products defines the difference between fixed and variable costs. When, through an efficient administration of outsourcing management, the company govern to transform fixed costs into variable costs, it has a strong possibility of achieving relevant competitive advantages in terms of costs.

According to Mcivor (2005), for there to be the possibility of converting fixed costs into variables, it is fundamentally necessary that two situations converge: the decision to use outsourcing as a management model (in whole, in part, in some process or even some specific department); and a perfect identification of the fixed costs that one wants to transform into variable. Then, when defining the application of outsourcing, the company must decide on how it will be implemented and, more than that, how it will be managed.

Therefore, based on what has been seen, the implementation and management of outsourcing in the investigated companies is analysed, to find out what competitive advantages were obtained in terms of costs, the method of managing the outsourcing process and what are the effects on the results entities surveyed. For this, an adequate methodology is adopted, which will be better explained in the following topic.

\section{Methodology Applied in This Research}

Two enterprises situated in the city of Juiz de Fora, State of Minas Gerais, in Brazil, took part in the research. The main criterion for choosing the organizations was that the company has adopted, in the period considered, the outsourcing methodology in its operations. Thus, two companies in the industrial sector were selected. One operates in the area of production of aluminium parts (locksmiths), in the manufacture of frames, doors, grilles, stained glass and similar parts. The other works in the processing of artificial fibbers produced from the treatment of cellulose. The development of the work was done virtually and in loco, when the analysis of the financial statements and other management reports of the companies was carried out, covering the period from 2015 to 2019. Considering that the companies did not give authorization to identify them, we chose to characterize them as Enterprise Bravo and Enterprise Charlie.

Due to the need to investigate and detail the phenomena observed in order to deepen their understanding, the quantitative and qualitative method was used. Thereby, for the design of the research, a systematic, applied, planned and directed case study was used, aimed at obtaining valid data and information in order to obtain concrete qualitative-quantitative results on the subject (YIN, 2005). 
The research also has a descriptive, exploratory characteristic, highlighting the problem through a bibliographic survey and interviews with the target audience, using a structured questionnaire, in order to identify the problem within the proposed situation for the research (YIN, 2005; GIL, 2010).

For the data collection, an instrument was used consisting of 8 (eight) management process efficiency indicators (iTEPG), 4 (four) analysis criteria and 5 (five) evaluation standards, intended for the formation of the Efficiency Rate, presented in the Table below:

Table 1. Instruments for the formation of the BOP Efficiency Rate

\begin{tabular}{|c|c|c|}
\hline Efficiency indicators & Analysis Criteria & Evaluation Standards \\
\hline \multicolumn{3}{|l|}{ Efficiency of process effectiveness verification } \\
\hline \multicolumn{3}{|l|}{ Efficiency of training and qualification } \\
\hline Efficiency of decision implementation & Application & Very low - de 1 a 1.50 \\
\hline Efficiency of process supervision & Documentation & Low - de 1.51 a 2.50 \\
\hline \multirow{2}{*}{ Efficiency of risk management } & Documentation & Medium - de 2.51 a 3.25 \\
\hline & Validation & High - de 3.25 a 4.25 \\
\hline Efficiency of evaluation and control of results & Results & Very high - de 4.26 a 5.00 \\
\hline \multicolumn{3}{|l|}{ Efficiency of information flow } \\
\hline Efficiency of Feedback process & & \\
\hline
\end{tabular}

Source: Built by the authors from BOUKADI (2019). ZAROUR, Karim. BENMERZOUG (2019). MAIA (2017).

The formulation of calculations and the mathematical methodology is explained as follows:

a) Calculation of the Management Process Efficiency Index - iTEPG: the Management Process Efficiency Index is the arithmetic average of the 8 (eight) analysed rates represented by the following equation:

$$
i T E P G=\sum_{q=1}^{8} i q / 8
$$

b) The objective is to find the efficiency index of the management process structure and the respective rates of the 8 (eight) efficiency indicators, where:

$$
i T E P G=i E V e p+i E T c+i E I d+i E S p+i E G r+i E A c r+i E F i n f o+i E P f b k
$$

1) iEVep: Efficiency rate of process effectiveness verification;

2) iETc: Efficiency rate of training and qualification;

3) iEId: Efficiency rate of decision implementation;

4) iESp: Efficiency rate of process supervision;

5) iEGr: Efficiency rate of risk management;

6) iEAcr: Efficiency rate of evaluation and control of results;

7) iEFinfo: Efficiency rate of information flow; and

8) iEPfbk: Efficiency rate of Feedback process.

c) For the formation of the Efficiency Rate, an instrument consisting of 4 (four) indicators and 5 (five) was based on the table below: 
Table 2. Formation of the BOP Efficiency Indicator Rate

\begin{tabular}{|c|c|c|c|c|}
\hline $\begin{array}{l}\text { Analysis } \\
\text { Criteria }\end{array}$ & Description & & & \\
\hline 1. Application & $\begin{array}{l}\text { Verification if the company applies } \\
\text { the procedure. }\end{array}$ & & & \\
\hline $\begin{array}{l}2 . \\
\text { Documentation: }\end{array}$ & $\begin{array}{l}\text { Presentation of documentation or } \\
\text { any evidence that proves that the } \\
\text { company applies the procedure. }\end{array}$ & \multicolumn{3}{|c|}{ Evaluation Standards } \\
\hline \multirow{4}{*}{$\begin{array}{l}\text { 3. Documentation } \\
\text { Validation: }\end{array}$} & \multirow{4}{*}{$\begin{array}{l}\text { Analysis of the documentation } \\
\text { presented to verify whether there } \\
\text { are sufficient elements to prove that } \\
\text { the procedure is applied and that the } \\
\text { results shown have evidence to } \\
\text { confirm the veracity. }\end{array}$} & $\begin{array}{l}\text { Efficienc } \\
\text { y Rate } \\
\text { interval }\end{array}$ & $\begin{array}{l}\text { Classificati } \\
\text { on criteria }\end{array}$ & $\begin{array}{l}\text { Impact on } \\
\text { results }\end{array}$ \\
\hline & & $\begin{array}{c}\text { From } 1 \text { to } \\
1.50\end{array}$ & Very low & Very low \\
\hline & & $\begin{array}{l}\text { From } \\
1.51 \text { to } \\
2.50\end{array}$ & Low & Low \\
\hline & & $\begin{array}{l}\text { From } \\
2.51 \text { to } \\
3.25\end{array}$ & Medium & Medium \\
\hline & \multirow{2}{*}{$\begin{array}{l}\text { Presentation of the results obtained } \\
\text { through the application of the } \\
\text { procedure (reports that indicate } \\
\text { which results were achieved; which }\end{array}$} & $\begin{array}{l}\text { From } \\
3.26 \text { to } \\
4.25\end{array}$ & High & High \\
\hline 4. Results & & $\begin{array}{l}\text { From } \\
4.26 \text { to } \\
5.00\end{array}$ & Very high & Very high \\
\hline
\end{tabular}

risks were avoided; which losses and/or damages were avoided or minimized).

Source: Built by the authors from the literature used in the research.

d) Thus, the Efficiency Rate Indicator matrix is composed as follows:

$$
i E X_{D}=\frac{A_{\text {ind }}+D_{\text {ind }}+V_{\text {ind }}+R_{\text {ind }}}{4}
$$

e) The efficiency rate indicator is the arithmetic average of the 4 (four) indicators analysed. Being:

$\mathrm{iE}$ : Efficiency rate indicator;

$\mathrm{X}_{\mathrm{D}}$ : Description of the dimension being analysed;

$\mathrm{A}_{\text {ind }}$ : Description application indicator;

$\mathrm{D}_{\text {ind }}$ : Documentation indicator used;

$\mathrm{V}_{\text {ind }}$ : Documentation Validation Indicator;

$\mathrm{R}_{\text {ind }}$ : Results indicator. 
f) For the calculation of the Impact Rate on the financial results, the efficiency indication rate indicators listed in Table 1 and the result of the Efficiency Rate Indicator (iEXD) are used, in the following mathematical composition:

$$
i I R F=\frac{1}{i E X_{D}}
$$

g) The management impact rate is inversely proportional to the Efficiency Rate Indicator, that is, the lower the efficiency index (iEXD), the greater the impact, being:

iIRF: Management impact rate.

\section{iE: Efficiency Rate Indicator;}

$\mathrm{X}_{\mathrm{D}}$ : Description of the dimension being analysed.

Once the consolidation of the 8 (eight) indexes related to the efficiency indicators of the management process was carried out, the Excel application was used to transport the data using the proposed mathematical model, in order to visualize the impacts on the results individually and collectively, as shown in the matrix below:

Table 3. Impact Matrix on Financial Results - Structure of the BPO Management Process

\begin{tabular}{|c|c|c|c|c|c|c|c|c|c|}
\hline $\begin{array}{c}\text { Rate } \\
\text { Description }\end{array}$ & $=$ & Application & $*$ & Documentation & $*$ & $\begin{array}{c}\text { Documentation } \\
\text { validation }\end{array}$ & $*$ & Results & $\begin{array}{l}\text { Impact rate on } \\
\text { financial } \\
\text { results }\end{array}$ \\
\hline iEVep & $=$ & EAvep & * & EDvep & $*$ & EVvep & $*$ & ERvep $=$ & iIRFg \\
\hline $\mathrm{iETc}$ & $=$ & EAtc & $*$ & EDtc & $*$ & EVtc & $*$ & ERtc $=$ & iIRFg \\
\hline iEId & $=$ & EAid & $*$ & EDid & $*$ & EVid & $*$ & ERid = & iIRFg \\
\hline $\mathrm{iESp}$ & $=$ & EAsp & * & EDsp & $*$ & EVsp & $*$ & ERsp $=$ & iIRFg \\
\hline $\mathrm{iEGr}$ & $=$ & $\overline{\text { EAgr }}$ & $*$ & EDgr & & $\mathrm{EVgr}$ & $*$ & ERgr $=$ & iIRFg \\
\hline iEAcr & $=$ & EAacr & * & EDacr & $*$ & EVacr & $*$ & ERacr $=$ & iIRFg \\
\hline iEFinfo & $=$ & EAfinfo & $*$ & EDfinfo & $*$ & EVfinfo & $*$ & ERfinfo $=$ & iIRFg \\
\hline iEPfbk & $=$ & EApdbk & $*$ & EDpdbk & $*$ & EVpdbk & $*$ & ERpdbk = & iIRFg \\
\hline TOTAL & $=$ & iETApg & $*$ & iETDpg & $*$ & iETVpg & $*$ & iETRpg $=$ & iTIRFpg \\
\hline
\end{tabular}

Source: Built by the authors based on the literature used in the research.

Where:

iE: Efficiency Rate Indicator.

E: Efficiency.

iET: Total Efficiency Rate.

iIRF: Management impact rate.

$$
\mathrm{iETApg}=\frac{\begin{array}{c}
\mathrm{iEVep}+\mathrm{iETc}+\mathrm{iEId}+\mathrm{iESp}+\mathrm{iEGr}+\mathrm{iEAcr}+\mathrm{iEFinfo}+ \\
\mathrm{iEPfbk}
\end{array}}{8}
$$

iETApg - Total Efficiency Rate of the Management Process Application Indicator: Corresponds to the efficiency index in relation to the application of the management process: It is represented by the arithmetic average of the application of the 8 (eight) analysed indicators. 
From a qualitative point of view, the structure of the management process for outsourcing, the specific reports and the Profit \& Losses (P\&L) for the period from 2015 to 2019 was examined. The results are shown in the following topic.

\section{Results and Discussions}

After analysing the reports, documents and the P\&L of the Enterprise Bravo and Enterprise Charlie in the period from 2015 to 2019, it was possible to verify the performance of each one in relation to profitability and cost fluctuations due to the transformation of fixed costs into variable costs resulting from the implementation of the outsourcing. It can be seen in the following table that the companies showed different performances, behold:

Table 4. Enterprise Bravo Financial Results

\begin{tabular}{lrrrrr}
\hline \multirow{2}{*}{ Description } & \multicolumn{5}{c}{ Enterprise Bravo } \\
\cline { 2 - 6 } & 2015 & 2016 & 2017 & 2018 & \multicolumn{1}{c}{2019} \\
\hline (=) Net Sales & $\mathrm{R} \$ 455.040$ & $\mathrm{R} \$ 529.200$ & $\mathrm{R} \$ 806.050$ & $\mathrm{R} \$ 1.014 .624$ & $\mathrm{R} \$ 1.336 .720$ \\
\hline Quantity produced (units) & 10,112 & 11,025 & 16,450 & 19,512 & 23,870 \\
\hline (-) Variable costs & $\mathrm{R} \$ 204.768$ & $\mathrm{R} \$ 243.432$ & $\mathrm{R} \$ 378.844$ & $\mathrm{R} \$ 487.020$ & $\mathrm{R} \$ 654.993$ \\
\hline (-) Fixed costs & $\mathrm{R} \$ 182.016$ & $\mathrm{R} \$ 137.592$ & $\mathrm{R} \$ 203.793$ & $\mathrm{R} \$ 245.556$ & $\mathrm{R} \$ 326.930$ \\
\hline (=) Operating result & $\mathrm{R} \$ 68.256$ & $\mathrm{R} \$ 148.176$ & $\mathrm{R} \$ 223.414$ & $\mathrm{R} \$ 282.048$ & $\mathrm{R} \$ 354.797$ \\
\hline (\%) Profitability & $15 \%$ & $28 \%$ & $28 \%$ & $28 \%$ & $27 \%$ \\
\hline
\end{tabular}

Source: Research data, based on Neves and Martins (2012), adapted.

Table 5. Enterprise Charlie Financial Results

\begin{tabular}{|c|c|c|c|c|c|}
\hline \multirow{2}{*}{ Description } & \multicolumn{5}{|c|}{ Enterprise Charlie } \\
\hline & 2015 & 2016 & 2017 & 2018 & 2019 \\
\hline (=) Net Sales & $\mathrm{R} \$ 2.409 .500$ & $\mathrm{R} \$ 2.873 .000$ & $\mathrm{R} \$ 3.165 .400$ & $\mathrm{R} \$ 3.532 .250$ & $\mathrm{R} \$ 3.956 .600$ \\
\hline Quantity produced (units) & 39,500 & 44,200 & 46,550 & 49,750 & 54,200 \\
\hline (-) Variable costs & $\mathrm{R} \$ 1.228 .845$ & $\mathrm{R} \$ 1.493 .960$ & $\mathrm{R} \$ 1.835 .932$ & $\mathrm{R} \$ 2.189 .995$ & $\mathrm{R} \$ 2.571 .790$ \\
\hline (-) Fixed costs & $\mathrm{R} \$ 1.156 .560$ & $\mathrm{R} \$ 1.149 .200$ & $\mathrm{R} \$ 886.312$ & $\mathrm{R} \$ 1.059 .675$ & $\mathrm{R} \$ 1.226 .546$ \\
\hline (=) Operating result & $\mathrm{R} \$ 24.095$ & $\mathrm{R} \$ 229.840$ & $\mathrm{R} \$ 443.156$ & $\mathrm{R} \$ 282.580$ & $\mathrm{R} \$ 158.264$ \\
\hline (\%) Profitability & $1 \%$ & $8 \%$ & $14 \%$ & $8 \%$ & $4 \%$ \\
\hline
\end{tabular}

Source: Research data, based on Neves and Martins (2012), adapted.

Comparing the results of the Enterprise Bravo (Table 4) with those achieved by the Enterprise Charlie (Table 5) in the period between 2015 to 2019, it appears that the Enterprise Bravo reduced fixed costs from 40\% to $25 \%$, while the Enterprise Charlie reduced from $48 \%$ to $17 \%$. The average annual reduction in fixed costs for both was $3 \%$. In relation to variable costs, it can be seen that Enterprise Bravo went from $45 \%$ to $49 \%$ (increase of $4 \%$ in the period). The Enterprise Charlie increased its variable costs from $51 \%$ to $54 \%$ (14 percentage points). From the foregoing, it is clear that the Enterprise Bravo had a better balance between the reduction of fixed costs and the increase in variable costs, whereas the Enterprise Charlie demonstrates that variable costs rose far beyond those reduced by fixed costs, which may indicate a problem in management of these costs related to outsourcing.

In order to deepen the analysis of the performance of these two organizations, the issue of their profitability in the period is also analysed. The Enterprise Bravo had a growth of 12 percentage points in profitability (from $15 \%$ in 2015 to $27 \%$ in 2019) while the profitability of the Enterprise Charlie grew only $3 \%$ (from 1\% to 4\%). Therefore, the Enterprise Bravo had an average annual growth of $2.31 \%$ on its profitability, while the Enterprise Charlie grew only $0.60 \%$ per year. This finding raises the following question: if the Enterprise Charlie reduced fixed costs and increased (albeit disproportionately) variable costs, it would be correct that its profitability had also grown in 
proportion to the transfer of fixed to variable costs, in the same way that occurred with the Enterprise Bravo? The answer to this question may be related to the efficiency of outsourcing management and its relationship with cost management. In this sense, the administration performance is analysed based on the literature applied in this study and on the models presented in Tables 2 and 3 of the methodology of this research.

Table 6. Efficiency Rate of Enterprise Bravo's BPO management process

\begin{tabular}{|c|c|c|c|c|c|c|c|}
\hline Item & i (rate) & Rate Description & 氙 & $\stackrel{\overline{\bar{J}}}{\stackrel{\Xi}{\Xi}}$ & لَّ & $\stackrel{n}{\vec{\Xi}}$ & $\begin{array}{c}\text { Total index of } \\
\text { negative impact on }\end{array}$ \\
\hline 1 & 1.50 & $\begin{array}{l}\text { Efficiency rate of process effectiveness } \\
\text { verification }\end{array}$ & 4 & 5 & 4 & 4 & $24 \%$ - LOW IMPACT \\
\hline 2 & 2.25 & Efficiency rate of training and qualification & 4 & 4 & 3 & 4 & $27 \%$ - LOW IMPACT \\
\hline 3 & 1.50 & Efficiency rate of decision implementation & 4 & 4 & 4 & 4 & $25 \%$ - LOW IMPACT \\
\hline 4 & 2.25 & Efficiency rate of process supervision & 4 & 5 & 5 & 4 & $\begin{array}{l}22 \% \text { - VERY LOW } \\
\text { IMPACT }\end{array}$ \\
\hline 5 & 1.00 & Efficiency rate of risk management & 3 & 2 & 1 & 2 & $\begin{array}{l}50 \%-\mathrm{HIGH} \\
\text { IMPACT }\end{array}$ \\
\hline 6 & 1.75 & $\begin{array}{l}\text { Efficiency rate of evaluation and control of } \\
\text { results }\end{array}$ & 4 & 4 & 3 & 4 & $\begin{array}{l}27 \% \text { - LOW } \\
\text { IMPACTO }\end{array}$ \\
\hline 7 & 2.00 & Efficiency rate of information flow & 3 & 3 & 3 & 3 & $\begin{array}{l}\text { 33\% - MEDIUM } \\
\text { IMPACT }\end{array}$ \\
\hline 8 & 1.25 & Efficiency rate of Feedback process & 4 & 4 & 3 & 3 & $29 \%$ - LOW IMPACT \\
\hline $\mathrm{T}$ & 1.25 & TOTAL & 3.75 & 3.88 & 3.25 & 3.50 & $\begin{array}{l}33 \% \text { - MEDIUM } \\
\text { IMPACT }\end{array}$ \\
\hline
\end{tabular}

Source: Built by the authors based on the literature used in the research.

Table 7. Efficiency Rate of Enterprise Charlie's BPO management process

\begin{tabular}{|c|c|c|c|c|c|c|c|}
\hline Item & (rate) & Rate Description & 节 & & 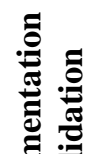 & $\stackrel{\mathscr{n}}{\tilde{\sigma}_{0}}$ & $\begin{array}{c}\text { Total index of } \\
\text { negative impact on }\end{array}$ \\
\hline 1 & 1.50 & $\begin{array}{l}\text { Efficiency rate of process effectiveness } \\
\text { verification }\end{array}$ & 2 & 1 & 1 & 2 & $\begin{array}{c}\text { 67\% - VERY HIGH } \\
\text { IMPACT }\end{array}$ \\
\hline 2 & 2.25 & Efficiency rate of training and qualification & 3 & 2 & 2 & 2 & $\begin{array}{l}\text { 44\% - HIGH } \\
\text { IMPACT }\end{array}$ \\
\hline 3 & 1.50 & Efficiency rate of decision implementation & 2 & 1 & 1 & 2 & $\begin{array}{c}\text { 67\% - VERY HIGH } \\
\text { IMPACT }\end{array}$ \\
\hline 4 & 2.25 & Efficiency rate of process supervision & 3 & 2 & 2 & 2 & $\begin{array}{l}\text { 44\% - HIGH } \\
\text { IMPACT }\end{array}$ \\
\hline
\end{tabular}




\begin{tabular}{cclcccc}
\hline 5 & 1.00 Efficiency rate of risk management & 1 & 1 & 1 & 1 & $\begin{array}{c}\text { 100\% - VERY HIGH } \\
\text { IMPACT }\end{array}$ \\
\hline 6 & $1.75 \begin{array}{l}\text { Efficiency rate of evaluation and control of } \\
\text { results }\end{array}$ & 2 & 2 & 1 & 2 & $\begin{array}{c}57 \% \text { - HIGH } \\
\text { IMPACT }\end{array}$ \\
\hline 7 & 2.00 Efficiency rate of information flow & 2 & 2 & 2 & 2 & $\begin{array}{c}50 \% \text { - HIGH } \\
\text { IMPACT }\end{array}$ \\
\hline 8 & 1.25 Efficiency rate of Feedback process & 2 & 1 & 1 & 1 & $\begin{array}{c}80 \% \text { - VERY HIGH } \\
\text { IMPACT }\end{array}$ \\
\hline $\mathrm{T}$ & 1.25 TOTAL & 2.1 & 1.5 & 1.4 & 1.8 & $\begin{array}{c}80 \%-\text { VERY HIGH } \\
\text { IMPACT }\end{array}$ \\
\hline
\end{tabular}

Source: Built by the authors based on the literature used in the research.

Comparing the performance of the two companies, the following conclusion is reached:

Table 8. Joint analysis of the performance of companies in relation to the efficiency of the BPO management process

\begin{tabular}{ccccccccccc}
\hline Description & \multicolumn{1}{c}{ Application } & \multicolumn{1}{c}{ Documentation } & $\begin{array}{c}\text { Documentation } \\
\text { Validation }\end{array}$ & Results & \multicolumn{2}{c}{$\begin{array}{c}\text { i (rate) } \\
\text { iTEEPD Total }\end{array}$} \\
\hline Enterprise & B & C & B & C & B & C & B & C & B & C \\
\hline Total Efficiency Rate & 3.75 & 2.13 & 3.88 & 1.50 & 3.25 & 1.38 & 3.50 & 1.75 & 3.00 & 1.25 \\
\hline Efficiency Rate Rating & High & Low & High & $\begin{array}{l}\text { Very } \\
\text { Low }\end{array}$ & High & $\begin{array}{l}\text { Very } \\
\text { Low }\end{array}$ & High & Low Medium & $\begin{array}{l}\text { Very } \\
\text { Low }\end{array}$ \\
\hline $\begin{array}{c}\text { Negative impact on financial } \\
\text { results (operating result and } \\
\text { profitability) }\end{array}$ & Low & High & Low & $\begin{array}{c}\text { Very } \\
\text { High }\end{array}$ & Low & $\begin{array}{c}\text { Very } \\
\text { High }\end{array}$ & Low & High Medium & $\begin{array}{l}\text { Very } \\
\text { High }\end{array}$ \\
\hline
\end{tabular}

Source: Built by the authors from research data.

As seen in Table 8, based on the methodology used in the work and the criteria adopted in this research (item 4), Enterprise Charlie's Management Process Efficiency Rate (iTEPG) was 1.25 points, while Enterprise Bravo's iTEPG was 3.00. This can be completed by analysing Table 7 where the Enterprise Charlie obtained low scores in terms of outsourcing management, notably in all the items evaluated, namely: the effectiveness of the process, training and qualification; the implementation of the decision; oversight of the process; risk management; the evaluation and control of results; the flow of information; and the feedback process. It is also noted that the negative impact on the profitability of the entity was considered "very high". The analysis showed that the company, given these management deficiencies, has an $80 \%$ risk of being impacted on its profitability. With regard to the Enterprise Bravo (Table 6), it was found that it had only a $33 \%$ chance of suffering a negative impact on its profitability. Although it is still a representative percentage, for the purposes of the criteria adopted in this research, it was considered as medium risk.

This finding makes the analysis turn to the operational results of the companies in terms of profitability. Firstly, as seen in Table 4 (Enterprise Bravo Financial Results), the Enterprise Bravo has achieved sustainable growth since 2015, when it adopted the outsourcing process. It is noted that the aforementioned company grew, in terms of profitability, from $15 \%$ to $28 \%$ from 2015 to 2016 and practically maintained this pace of growth until 2019, the last year of the period under review, which denotes the maintenance of earnings. Combining the profitability obtained by the Enterprise Bravo (shown in Table 4), and the degree of reasonable efficiency in the BPO management process verified in Table 6, it can be inferred that the sustained growth of profitability observed in the Enterprise Bravo is related to the good efficiency index of the BPO management process.

In the same comprehension, although with opposite results, there is a relationship between the efficiency of the BPO management process and the profitability earned in the period by the Enterprise Charlie. As can be seen in Table 8, 
the Enterprise Charlie's BPO management process efficiency index was 1.25, having been classified as "very low" and "very high" risk of negative impact on financial results (operational results and profitability). This conclusion is even more evident when looking at Table 5 (Enterprise Charlie Financial Results), in which it is verified that the company started the process of transforming fixed costs into variable costs through outsourcing, obtaining an expressive result between the years 2015 to 2016, while profitability jumped from $1 \%$ to $8 \%$ and in 2017 when it reached the level of $14 \%$. However, as of 2018 , profitability dropped to $8 \%$, reaching only $4 \%$ in 2019 , impacting the operating result (loss of revenue) and the precipitous drop in profitability.

From what has been found, it is understood that there is sufficient evidence to conclude that the higher the efficiency index of the BPO management process, lower will be the negative impact on the company's financial results. Thereby, it appears that, in order for the cost competitiveness acquired as a result of the implementation of outsourcing to be maintained, it is essential an efficient management in the related processes.

\section{Conclusion}

The objective of this paper was to discover the impact of the level of efficiency in the management of outsourcing causes on the company's financial results. For this purpose, two companies in the industrial sector that adopted the outsourcing method in their operations were selected. To enable the study, the financial reports and documents of the companies in the period from 2015 to 2019 were investigated. In addition, the financial performance of these organizations in that period was analysed, in order to measure the effects on the financial results of these companies in due to the efficiency in the outsourcing management process.

For the verification of the financial progress, it was seen that, after the implementation of outsourcing, both Enterprise Bravo and Enterprise Charlie were able to reduce fixed costs and increase variable expenses and, therefore, maximize the financial results, both in terms of operating outcome and in terms of profitability, especially in 2016 and 2017. This situation allows to confirm the thesis of several works that claim it is possible to obtain competitive advantages in terms of costs from the transformation of fixed costs into variable costs through the outsourcing process.

However, from 2018 onwards there was a stabilization in Enterprise Bravo's profitability and a significant drop in Enterprise Charlie's financial results (Tables 4 and 5). It was also noted that, when considering the profitability over the period of five years, it was found that the Enterprise Bravo had a much better performance than the Enterprise Charlie, considering that it had a small growth (only 3\%), while the other company grew $12 \%$ in the same period. In view of this, it was necessary to advance in the investigation to understand the reasons for such different results, notably because both companies were able to reduce fixed costs, increase variable costs and maximize revenue.

In sequence, an analysis of the structure of the outsourcing management was carried out. The Business Process Outsourcing (BPO) method was used as a basis. The analysis model was organized from a model built by the authors, consisting of 8 (eight) indicators of efficiency of the management process (iTEPG), 4 (four) analysis criteria and 5 (five) evaluation standards, aiming the formation of the Efficiency Rate, as shown in Table 1. Once this was done, a mathematical model was proposed in order to calculate the efficiency index of the BPO management process.

The results showed that the Total Efficiency Rate of Enterprise Charlie's BPO management process was 1.25 points. Thus, the efficiency rate of this company was considered "very low", which imposed a "very high" risk of negative impact on the financial results (operating result and profitability), as shown in Table 8. Otherwise, the Management Efficiency of Enterprise Bravo's BPO was 3.00 points, classified as "medium". So, the risk of having a negative impact on Enterprise Bravo's financial results was also considered as "medium" risk.

Therefore, comparing the profitability obtained by the Enterprise Bravo (shown in Table 4) and the degree of reasonable efficiency in the BPO management process verified in Table 6, it can be inferred that the sustained growth of profitability observed in the Enterprise Bravo is related to the good efficiency index of the BPO management process. In the same direction, the results of the Enterprise Charlie demonstrate that, despite of obtaining competitive advantages in costs in face of the adoption of outsourcing, the company was not able to sustain the growth of the financial operational results and, consequently, lost profitability. In this sense, was possible to verify that the negative impacts on the financial results on this company are related to the low level of efficiency in the BPO management process.

Thereby, it is possible to conclude that there is enough evidence to understand that the sustainability of the financial results obtained by companies from the implementation of outsourcing is directly related to the ability of managers to undertake efficiency in the management of the outsourcing process. 
Finally, it is emphasized that the research does not have the power to determine, by itself, the negative results found are solely due to poor management of the outsourcing process, since other organizational aspects were not measured. However, it is possible to state with reasonable certainty that poor outsourcing management contributes decisively to negatively impact of the financial results of organizations.

\section{References}

Bomtempo, M. P., \& Quental, J. V. C. (1998, May/Aug). Outsourcing in the final processing of the pharmaceutical and veterinary industries. Rev. adm. contemp., 2(2).

Boukadi, K., Grati, R., Rekik, M., \& Ben-abdallah, H. (2019, August). Business Process Outsourcing for Cloud Containers: How to Find the Right Deployment?. Future Generation Computing Systems Journal, 97, 397-408. https://doi.org/10.1016/j.future.2019.02.069

Eckert, A., Martins, L. M. R., \& Gonçalves, R. B. (2017). Business Process Outsourcing (BPO): An Analysis of the Two Characteristics in Midsize Companies. Caxias do Sul University: PUCRS/UFRGS. https://doi.org/10.5965/2316419006092017015

Ellram, L. M., Tate, W. L., \& Billington, C. (2008). Offshore outsourcing of professional services: a transaction cost economics perspective. Journal of Operations Management, 26(2), 148-163. https://doi.org/10.1016/j.jom.2007.02.008

Gil, A. C. (2010). How to design research projects (5 ed.). São Paulo: Atlas.

Machado, M. W. K. (ORG). (2018). Controllership, Cost Management and Finance. Ponta Grossa (PR): Atena Editora.

Martins, E. (2018). Cost accounting. 11 ${ }^{\text {a }}$ Edição, Editora Atlas, São Paulo.

Mcivor, R. (2005). The outsourcing process: strategies for evaluation and management. Cambridge: Cambridge University Press. https://doi.org/10.1017/CBO9780511543425

Neves, H. de C., \& Martins, P. do C. (2012, November). Learn why Outsourcing Improves Business Profitability. Revista Food Ingredients Brazil, (23), 50-52.

Padoveze, C. L. (2018). Cost Accounting, Theory, Practice, Integration with Information Systems (ERP). $1^{\text {a }}$ Edição, Editora Cengage Learning, São Paulo.

Rezende, L. (2019). Global Outsourcing Perspectives: Trends, technology and innovation for outsourcing. Deloitte $\begin{array}{lllll}\text { Foundation. } & \text { Retrieved } & 17 & \text { February } & \text { 2020, from }\end{array}$ https://www2.deloitte.com/global/en/pages/about-deloitte/articles/about-the-network.html

Uemoto Filho, R. (2019). Outsourcing services: what types and outlook in the Brazilian market. Vexia Gestão de Negócios: Rio de Janeiro. Retrieved 3 February 2020, from https://vexia.com.br/servicos-de-outsourcing-e-o-mercado-brasileiro/

Valença, M. C. de A., \& Barbosa, A. C. Q. (2002, April). Outsourcing and its impacts: a study in large organizations in Minas Gerais. Rev. Adm. Contemp., 6(1). https://doi.org/10.1590/S1415-65552002000100010

Yin, R. K. (2005). Case Study: Planning and Methods (3 ed.). Porto Alegre: Bookman.

Zarour, K., \& Benmerzoug, D. (2019). A Decision-Making Support for Business Process Outsourcing in a Multi-Cloud Environment. Revista International Journal of Decision Support System Technology. https://doi.org/10.4018/IJDSST.2019010104

\section{Copyrights}

Copyright for this article is retained by the author(s), with first publication rights granted to the journal.

This is an open-access article distributed under the terms and conditions of the Creative Commons Attribution license (http://creativecommons.org/licenses/by/4.0/). 